\title{
PENERAPAN PERATURAN PEMERINTAH TENTANG HOTEL SYARIAH (Implementasi Permen Parekraf No. 2 Tahun 2014 tentang Hotel Syariah, studi kasus pada Hotel Sofyan Inn Specia Bandung)
}

\author{
Irfan Setia Permana W \\ Mekanik Industri dan Desain, Politeknik TEDC Bandung \\ E-mail: setiairfanpermana@gmail.com
}

\begin{abstract}
Abstrak
Bisnis pariwisata syariah terutama hotel syariah menjadi salah satu sektor bisnis yang menawarkan keuntungan yang menggiurkan. Dimana semua masyarakat modern yang pergi ke luar kota dengan urusan pekerjaan atau sekedar berlibur sangat memerlukan jasa penginapan atau hotel. Salah satu bentuk perhatian pemerintah terhadap perkembangan bisnis syariah terutama hotel syariah ditunjukkan dengan adanya Peraturan Menteri Pariwisata dan Ekonomi Kreatif no. 2 tahun 2014 tentang Pedoman Penyelenggaraan Usaha Hotel Syariah yang menjadi landasan bagi para pengusaha pariwisata syariah untuk mendirikan usaha hotel yang menerapkan prinsip-prinsip syariah dalam aspek pengelolaan, produk, dan pelayanan. Tulisan ini dibuat untuk dapat mengetahui pedoman penyelenggaraan usaha hotel syariah dalam peraturan menteri pariwisata dan ekonomi kreatif No. 2 Tahun 2014, dan mengetahui bagaimana penerapannya dalam aspek pengelolaan, produk, dan pelayanan. Studi kasus yang dilakukan adalah pada Hotel Sofyan Inn Specia Bandung. Penelitian ini menggunakan jenis penelitian lapangan (field reseach). Analisis yang digunakan yaitu analisis deskriptif dengan tujuan mendeskripsikan data-data yang penulis kumpulkan tentang prinsip Islam dalam ekonomi dan hubungannya dengan peraturan pemerintah tentang pedoman penyelenggaraan usaha hotel syariah. Penelitian ini menyimpulkan bahwa hotel Sofyan Inn Specia masih belum memenuhi seluruh kriteria yang terdapat dalam peraturan menteri pariwisata dan ekonom kreatif No. 2 Tahun 2014, baik dalam aspek pengelolaan, produk, dan pelayanan. Oleh sebab itu, hotel ini masih belum bisa disebut sebagai usaha hotel syariah menurut peraturan menteri tersebut, dan belum bisa digolongkan menjadi golongan usaha hotel hilal-1 maupun hilal-2.
\end{abstract}

Kata Kunci: syariah, hotel, hilal, pemerintah

\begin{abstract}
Shariah tourism business, especially sharia hotels become one of the business sector that offers lucrative profits. Where all the modern society who go out of town with a job or just a vacation is in need of lodging services or hotels. One form of government attention to the development of sharia business, especially sharia hotels is shown by the minister of tourism and creative conomy no. 2 year 2014 on the Guidance of Sharia Business Operations which become the foundation for sharia tourism entrepreneurs to establish hotel business applying syariah principles in product, service and management aspects. This paper was made to be able to know about the guidance of the implementation of sharia hotels business in the regulation of tourism minister and creative economy No. 2 Year 2014, and know how its application in product, service, and management aspects. The case study was conducted at hotel Sofyan Inn Specia Bandung. This research uses field research type (field reseach). The data analysis used is descriptive analysis with the purpose of describing the data that the author collects about the principle of Islam in economy and its relation with the government regulation about the guidance of the implementation of syariah hotel business. This study concluded that Sofyan Inn Specia hotel still does not meet all the criteria contained in tourism ministerial and creative economy regulation no. 2 Year 2014, in terms of product, service, and management. Therefore, this hotel still can not be called as sharia hotel business according to the minister's regulation, and can not be classified into hotel business group of hilal-1 and hilal-2.
\end{abstract}

Keywords: sharia, hotel, hilal, government

\section{PENDAhUlUan}

Meningkatnya kesadaran masyarakat Indonesia yang mayoritas Muslim untuk menerapkan prinsip-prinsip syariat dalam berbagai aspek kehidupan salah satunya terlihat dalam perkembangan dunia ekonomi, bisnis dan pariwisata. Pada satu dekade terakhir, pariwisata berbasis syariah sudah menjadi trend baru dalam perkembangan pariwisata di berbagai belahan dunia termasuk Indonesia. Esensi dari banyak dan berkembangnya pariwisata syariah merujuk pada usaha untuk menyingkirkan segala hal yang dapat membahayakan bagi manusia dan diharapkan dapat mendekatkan manusia kepada hal yang akan membawa kebermanfaatan bagi dirinya maupun lingkungan. Pariwisata syariah telah banyak merambah ke berbagai sektor jasa, baik itu perhotelan maupun restoran pada sektorsektor tersebut saat ini menjadi incaran bagi wisatawan domestik maupun mancanegara. Contohnya seperti restoran yang menjual berbagai makanan halal yang sesuai ajaran Islam dan bisnis perhotelan yang menerapkan prinsip syariah (tidak menyediakan minuman beralkohol, hanya menyediakan makanan yang halal, dan menyediakan berbagai 
fasilitas penunjang ibadah, seperti al-Quran serta petunjuk arah kiblat di setiap kamar).

Salah satu bentuk perhatian pemerintah terhadap perkembangan bisnis syariah terutama hotel syariah ditunjukkan dengan adanya peraturan menteri pariwisata dan ekonomi kreatif No. 2 Tahun 2014 tentang pedoman atas penyelenggaraan usaha hotel syariah yang menjadi landasan bagi para pengusaha pariwisata syariah untuk mendirikan usaha hotel yang menerapkan prinsip-prinsip syariah dalam aspek pengelolaan, produk, dan pelayanan.

Berkembangnya bisnis syariah di Indonesia saat ini, mendorong penulis untuk melakukan penelitian tentang usaha pemerintah dalam memberikan payung hukum terhadap bisnis syariah tersebut. Namun demikian, karena luasnya obyek tentang bisnis syariah, dan untuk efektifitas serta efisiensi penelitian, maka kajian lebih difokuskan pada penerapan peraturan pemerintah tentang pedoman penyelenggaraan hotel syariah dengan studi kasus pada hotel Sofyan Inn Specia sebagai salah satu hotel yang berbasis syariah di kota Bandung.

\section{KAJIAN TEORITIK}

Terdapat beberapa unsur, sub unsur maupun aspek dalam bisnis hotel sehingga dapat disebut sebagai hotel syariah, seperti dalam pembahasan peraturan menteri pariwisata dan ekonomi kreatif (PAREKRAF) terkait pedoman penyelenggaraan usaha hotel syariah. Aspek tersebut meliputi produk, pelayanan dan pengelolaan. Usaha hotel syariah terbagi menjadi dua kategori, yaitu hotel syariah hilal-1 dan hotel syariah hilal-2. Adapun hotel syariah hilal 1menurut peraturan Menteri PAREKRAF yaitu hotel syariah yang di dalamnya memenuhi sebagian unsur syariah sesuai dengan penilaian usaha hotel syariah yang ditentukan oleh DSN-MUI. Sedangkan hotel syariah hilal 2 merupakan hotel syariah yang telah memenuhi seluruh unsur syariah sesuai dengan penilaian usaha hotel yang ditentukan juga oleh DSN-MUI.

Tata cara penilaian hotel syariah itu berbentuk daftar yang akan menilai, apakah sub unsur terpenuhi atau tidak. Misalnya, apakah persyaratan itu Mutlak (M) atau Tidak Mutlak (TM). Jika memenuhi sebagian unsur syariah sesuai dengan penilaian usaha hotel syariah yang ditentukan oleh DSN-MUI, maka hotel tersebut masuk kategori hotel syariah hilal 1, dan apabila di dalamnya memenuhi seluruh unsur syariah sesuai dengan penilaian usaha hotel yang ditentukan juga oleh DSN-MUI, maka hotel tersebut masuk kategori hotel syariah hilal-2.

Sebagai contoh sub-sub unsur dalam aspek produk yaitu lobby, dilihat dari ketersediaan pengeras suara, buku atau majalah Islami atau yang memiliki pesan moral, dan hiasan bernuansa islami. Kemudian, apakah terdapat informasi waktu shalat, informasi tertulis yang menyebut tidak menerima pasangan yang bukan muhrim, informasi tertulis tata cara menerima kunjungan tamu bagi penghuni hotel. Kemudian toilet umum, apakah tempat pembuangan air kecil terjaga pandangan dan juga tersedia alat bersuci dengan air yang praktis. Untuk Musholla, area tempat ibadah laki-laki dan perempuan terdapat pembatas dengan kondisi yang layak, juga ketersediaan perlengkapan shalat seperti mukena untuk wanita dan sarung untuk laki-laki, ketersediaan sistem ventilasi yang baik, pencahayaan, serta sound system. Tempat wudhunya yang terpisah antara laki-laki dan perempuan, serta tersedia saluran air bekas wudhu dengan kondisi baik.

Peraturan menteri tersebut juga menetapkan standarisasi dalam aspek pelayan, diantaranya aspek pelayanan di kantor depan, memberikan pilihan kamar yang bernuansa syariah, memberikan informasi masjid terdekat dengan hotel, memberikan informasi terkait waktu shalat, juga terdapat informasi kegiatan bernuansa Islami, memberikan informasi restoran/rumah makan halal, dalam hal menerima tamu yang berpasangan dilihat kesesuaian dengan kartu identitasnya, serta menyediakan lagu-lagu Islam pada waktu tertentu. Di ruang lobby dan koridor, pada setiap waktu shalat dikumandangkan adzan, serta diperdengarkan tilawah al-qur'an juga pada waktu tertentu.

Penggolongan hotel syariah dapat ditetapkan melalui sertifikasi usaha hotel syariah berdasarkan berdasarkan hasil penilaian terhadap pemenuhan kriteria mutlak yang berlaku bagi usaha hotel syariah yang meliputi aspek produk, aspek pelayanan, dan aspek pengelolaan.

Penerbitan sertifikat usaha hotel syariah dapat dilakukan dengan penilaian terhadapbeberapa hal, yaitu:

a. Pemenuhan persyaratan dasar

b. Pemenuhan dan pelaksanaan kriteria mutlak usaha hotel syariah sebagaimana diatur dalam peraturan Menteri pariwsata dan ekonomi kreatif tentang pedoman penyelenggaraan usaha hotel syariah.

Adapun hal mutlak yang harus ada pada usaha hotel syariah hilal-1 yaitu:

a. Terdiri dari 8 aspek produk, (delapan) unsur dan 27 (duapuluh tujuh) sub unsur,

b. Terdiri dari 6 (enam) unsur aspek pelayanan dan 20 (duapuluh) sub unsur,

c. Terdiri dari 2 (dua) unsur aspek pengelolaan dan 2 (dua) sub unsur.

Sedangkan kriteria mutlak bagi usaha hotel syariah hilal-2 meliputi:

d. Terdiri dari 11 (sebelas) unsur aspek produk dan 40 (empat puluh) sub unsur

e. Terdiri dari 10 (sepuluh) unsur aspek pelayanan dan 28 (dua puluh delapan sub unsur

f. Terdiri dari 3 (tiga) unsur aspek pengelolaan dan 6 (enam) sub unsur. 
Sertifikasi usaha hotel syariah mencakup tga hal, yaitu: memiliki sertifikat standar usaha hotel, memiliki penilaian mandiri usaha hotel syariah dan persiapan sistem jaminan halal $(\mathrm{SJH})$, dan memenuhi persyaratan pendaftaran. Adapun prosedur untuk mendapatkan sertifikat usaha hotel syariah yaitu sebagai berikut:

1. Melakukan pengajuan permohonan pendaftaran sertifiaksi kepada DSN-MUI, lalu DSN-MUI melimpahkan audit sistem jaminan halal kepada LPPOM MUI, dan menetapkan hasil audit sistem jaminan halal.

2. Apabila audit sistem jaminan halal tidak lengkap dan dinyatakan tidak lulus, maka pengusaha harus melengkapi ketentuan sesuai sistem jaminan halal. Apabila audit Sistem Jaminan Halal terpenuhi, LPPOM MUI melaporkan kepada komisi fatwa kemudian komisi fatwa memberikan rekomendasi kepada LPPOM MUI untuk menerbitkan sertifikat halal.

3. Selanjutnya DSN MUI harus melakukan audit terhadap pedoman usaha syariah, dan menetapkan hasil auditnya. Apabila hasil audit usaha syariah tidak lulus, maka pengelolah usaha syariah melakukan penilaian mandiri lagi. Akan tetapi, apabila lulus, DSN MUI melaporkan hasil audit kepada badan pengurus harian (BPH) MUI. Kemudian BPH MUI memberi rekomendasi kepada DSN MUI untuk menerbitkan sertifikat usaha syariah untuk diterima oleh pengusaha hotel yang bersangkutan.

4. Untuk pengawasan dan evaluasi hotel syariah, dilakukan oleh Menteri atau Gubernur atau Wali kota atau DSN MUI. Sedangkan untuk pengawasan terhadap hal teknis operasional khusus untuk kategori hotel Hilal 2, DSN MUI membentuk dewan pengawas syariah (DPS).

\section{METODOLOGI}

Langkah-langkah yang digunakan dalam penelitian ini meliputi beberap hal, yaitu metode, pendekatan, teknik pengumpulan data dan pengelolaan data, dengan detail sebagai berikut:

1. Metode Penelitian

Penelitian ini menggunakan metode Yuridis Empiris dengan melihat teori yang digunakan sebagai acuan kemudian mengkorelasikannya dengan objek yang sedang diteliti.

2. Pendekatan penelitian

Penelitian yang dilakukan peneliti adalah dengan menggunakan pendekatan kualitatif yaitu dengan mendeskripsikan obyek yang diteliti yaitu hotel Sofyan Inn Specia Bandung. Pendekatan kualitatif ini digunakan supaya mendapatkan hasil yang optimal.

3. Teknik pengumpulan data

Data penelitian yang digunakan dalam penelitian ini dikumpulkan dengan menggunakan teknik:
a. Observasi
b. Wawancara
c. Dokumentasi

4. Teknik Pengolahan Data

Dalam menganalisis data-data yang diperoleh selama penelitian, peneliti melakukan beberapa langkah, yaitu:

a. Kategorisasi

Hal yang dilakukan dalam proses kategorisasi ini adalah memilah milah setiap satuan data yang kemudian dikelompokkan sesuai bagian data yang sama dan diberi label tersendiri.

b. Reduksi data

Data yang diperoleh dilapangan akan disususn dalam bentuk uraian lengkap. Data tersebut selanjutnya akan dirangkum, dan dipilih dengan mengidentifikasi satuan (unit) yang ditemukan dalam data yang memiliki makna atau merupakan sebuah informasi bila dikaitkan dengan fokus atau masalah penelitian. Reduksi data dilakukan guna mendapatkan gambaran yang valid dari hasil observasi maupun wawancara. Reduksi data akan sangat membantu dalam memberikan kode terhadap hal hal yang dibutuhkan.

c. Display data

Display data yang dimaksud adalah dengan membuat model atau grafik sehingga keseluruhan data dan bagian bagian detail yang berkaitan dengan penelitian akan dapat dipetakan dengan jelas sehingga lebih mudah untuk dipahami.

\section{PEMBahasan}

Kementerian pariwisata dan ekonomi kreatif dalam peraturan Menteri No. 2 tahun 2014 menyatakan bahwa pengertian usaha perhotelan adalah penyediaan akomodasi berupa kamar di dalam suatu bangunan yang dapat dilengkapi dengan jasa pelayanan makan dan minum, kegiatan hiburan dan atau fasilitas lainnya secara harian dengan tujuan untuk memperoleh suatu keuntungan. Sedangkan usaha hotel yang berbasis syariah adalah usaha hotel yang penyelenggaraannya diharus memenuhi kriteria syariah sebagaimana dimaksud dalam peraturan Menteri pariwisata dan ekonomi kreatif tersebut.

Peraturan Menteri tersebut juga menyebutkan tentang kriteria yang harus dipenuhi bagi pengusaha hotel, khususnya hotel syariah agar usaha hotel syariah yang di didirikan tidak hanya berlabelkan syariah saja, namun sudah menerapkan prinsip-prinsip Islam dalam aspek pengelolaan, produk, maupun pelayanan.

Dalam rangka memudahkan terhadap identifikasi hotel dengan basis syariah dan pemenuhan unsur kesyariahan, terdapat dua golongan atau jenis hotel syariah yaitu hotel syariah hilal-1 dan hotel syariah hilal-2. Hotel 
syariah Hilal-1 yaitu hotel yang dinilai memenuhi seluruh kriteria usaha hotel syariah yang diperlukan untuk melayani kebutuhan minimal wisatawan muslim. Sedangkan penggolongan hotel syariah hilal-2 yaitu bagi hotel syariah yang dinilai memenuhi semua kriteria yang telah ditentukan untuk kebutuhan moderat wisatawan Muslim. Dalam kriteria hotel syariah, terdapat kriteria mutlak dan tidak mutlak.

Kriteria mutlak merupakan sebuah ketentuan dan persyaratan minimal tentang pengelolaan, produk, maupun pelayanan, yang harus terpenuhi dan dilaksanakan oleh pengelola hotel sehingga dapat dikategorikan sebagai usaha hotel syariah dan memperoleh sertifikat hotel syariah. Adapun kriteria tidak mutlak yaitu sebuah ketentuan atau aturan tentang pengelolaan, produk, maupun pelayanan sekunder untuk memenuhi atau menunjang kebutuhan tertentu wisatawan muslim. Yang paling penting dari proses ini yaitu didapatkannya sertifikat hotel syariah. Sertikat hotel syariah merupakan bukti tertulis yang diberikan oleh DSN-MUI pada usaha hotel yang telah memenuhi kriteria yang telah ditentukan, baik itu kriteria mutlak maupun tidak mutlak sesuai dengan peraturan Menteri pariwisata dan ekonomi kreatif.

Berdasarkan hasil wawancara dengan salah satu manager di hotel Sofyan Inn

Tabel 1. Kesesuaian kriteria
Specia, secara umum, hotel ini belum memenuhi semua kriteria mutlak dan tidak mutlak yang terdapat dalam peraturan Menteri tersebut baik dalam aspek pengelolaan, produk, ataupun pelayanan. Masih ditemukan beberapa hal yang belum sesuai dengan kriteria usaha hotel syariah sebagaimana yang tercantum dalam peraturan Menteri tersebut.

Adapun berdasarkan observasi atau pengamatan secara langsung di lapangan, penulis mencoba melakukan analisis kesesuaian usaha hotel syariah pada hotel Sofyan Inn Specia tersebut terhadap peraturan Menteri pariwisata dan ekonomi kreatif No. 2 Tahun 2014 berkaitan dengan pedoman penyelenggaraan hotel syariah. Sebelumnya, tabel yang disajikan dibawah ini merupakan kriteria mutlak dan tidak mutlak yang ditetapkan oleh majelis ulama Indonesia sebagai syarat untuk mendapatkan sertifikat hotel syariah hilal-1. Berikut ini adalah tabel kesesuaian antara kriteria yang terdapat dalam PERMEN PAREKRAF dengan aplikasi pada hotel Sofyan Inn Specia seperti pada tabel 1 berikut:

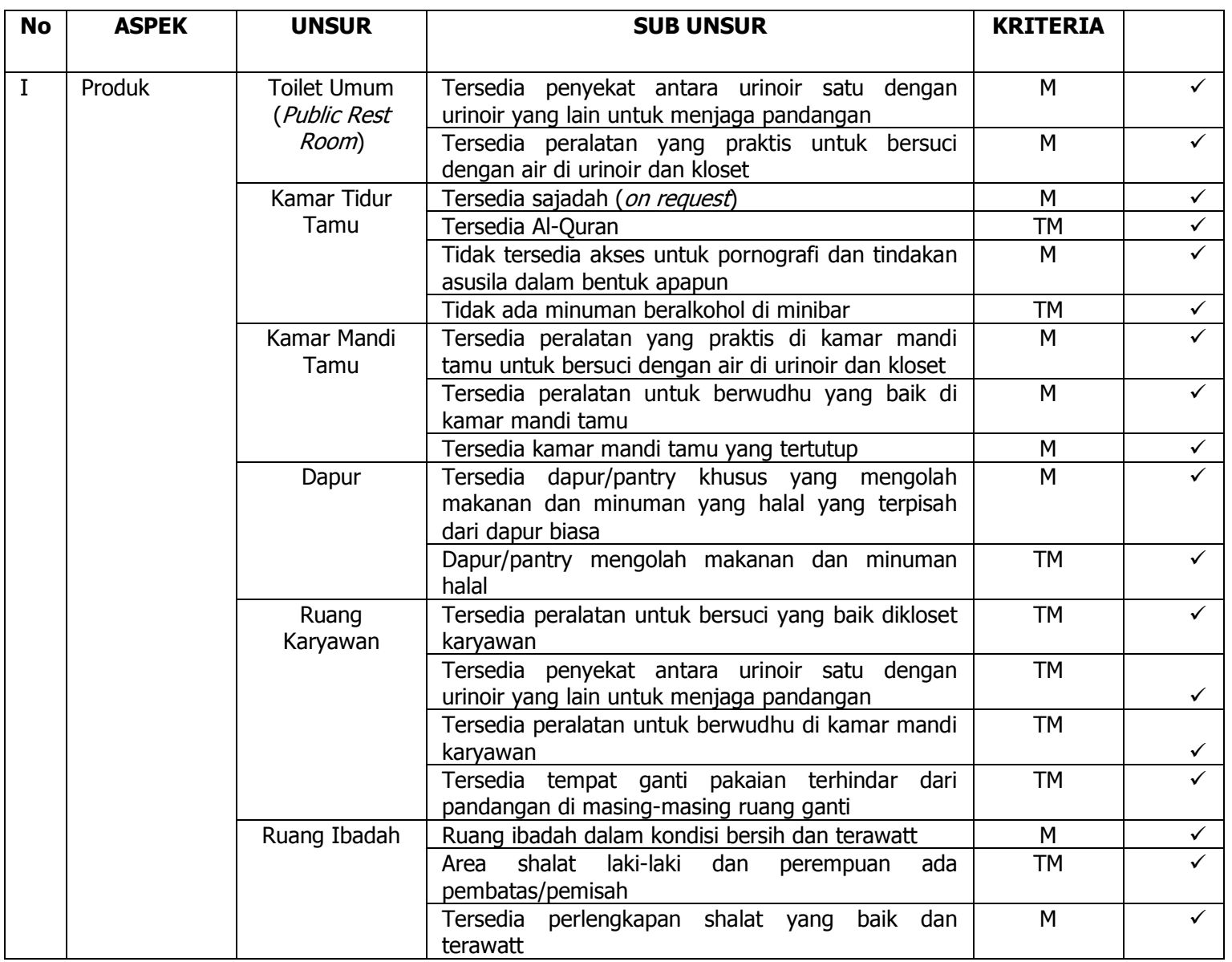




\begin{tabular}{|c|c|c|c|c|c|}
\hline & & & $\begin{array}{l}\text { Tersedia sirkulasi udara yang baik berupa alat } \\
\text { pendingin/kipas angina }\end{array}$ & M & $\checkmark$ \\
\hline & & & Tersedia pencahayaan yang cukup terang & M & \\
\hline & & & $\begin{array}{l}\text { Tersedia tempat wudhu laki-laki dan perempuan } \\
\text { terpisah }\end{array}$ & TM & $\checkmark$ \\
\hline & & & $\begin{array}{l}\text { Tersedia tempat wudhu dengan kondisi bersih dan } \\
\text { terawatt }\end{array}$ & M & $\checkmark$ \\
\hline & & & Tersedia instalasi air bersih untuk wudhu & M & $\checkmark$ \\
\hline & & & $\begin{array}{l}\text { Tersedia saluran pembuangan air bekas wudhu } \\
\text { dengan kondisi baik }\end{array}$ & TM & $\checkmark$ \\
\hline & & Kolam renang & $\begin{array}{l}\text { Tersedia dalam ruangan dan atau terhindar dari } \\
\text { pandangan umum }\end{array}$ & TM & - \\
\hline & & Spa & $\begin{array}{l}\text { Tersedia ruang terapi yang terpisah antara pria dan } \\
\text { wanita }\end{array}$ & TM & - \\
\hline & & & Tersedia bahan terapi yang berlogo halal resmi & TM & \\
\hline II & Pelayanan & Kantor Depan & $\begin{array}{l}\text { Melakukan seleksi terhadap tamu yang datang } \\
\text { berpasangan }\end{array}$ & TM & $\checkmark$ \\
\hline & & & Memberikan informasi Masjid terdekat dengan hotel & M & - \\
\hline & & & Memberikan informasi jadwal waktu shalat & $M$ & - \\
\hline & & & $\begin{array}{l}\text { Memberikan informasi kegiatan bernuansa Islami } \\
\text { (bila ada) }\end{array}$ & TM & - \\
\hline & & & Memberikan informasi restoran/rumah makan halal & TM & - \\
\hline & & Tata Graha & $\begin{array}{l}\text { Penyediaan perlengkapan shalat yang bersih dan } \\
\text { terawatt }\end{array}$ & M & $\checkmark$ \\
\hline & & & Penyediaan Al-Quran & TM & $\checkmark$ \\
\hline & & & $\begin{array}{l}\text { Menyiapkan area/ruangan untuk shalat Jumat (bila } \\
\text { tidak ada Mesjid yang dekat dengan hotel) }\end{array}$ & TM & $\checkmark$ \\
\hline & & Makan dan & Tersedia pilihan makanan dan minuman halal & $\mathrm{M}$ & $\checkmark$ \\
\hline & & minum & Menyediakan Ta'jil pada bulan Ramadhan & TM & \\
\hline & & & Menyediakan makan sahur pada bulan Ramadhan & M & \\
\hline & & $\begin{array}{l}\text { Olahraga, } \\
\text { rekreasi dan }\end{array}$ & $\begin{array}{l}\text { Pengaturan waktu penggunaan sarana kebugaran } \\
\text { dibedakan untuk pria dan wanita }\end{array}$ & TM & - \\
\hline & & kebugaran & $\begin{array}{l}\text { Instruktur kebugaran pria khusus untuk pria dan } \\
\text { wanita khusus untuk wanita }\end{array}$ & TM & - \\
\hline & & $\begin{array}{l}\text { Spa (Apabila } \\
\text { Ada) }\end{array}$ & $\begin{array}{l}\text { Spa hanya melayani pijat kesehatan dan perawatan } \\
\text { kecantikan }\end{array}$ & $M$ & - \\
\hline & & & $\begin{array}{l}\text { Terapis pria khusus untuk pria dan terapis wanita } \\
\text { khusus untuk wanita }\end{array}$ & TM & - \\
\hline & & & $\begin{array}{l}\text { Terapis menghindari menyentuh dan melihat area } \\
\text { sekitar organ intim }\end{array}$ & TM & - \\
\hline & & & $\begin{array}{l}\text { Apabila tersedia bak rendam tidak digunakan secara } \\
\text { bersama-sama }\end{array}$ & TM & - \\
\hline & & & $\begin{array}{l}\text { Apabila tersedia aktivitas olah fisik dan jiwa tidak } \\
\text { mengarah pada kemusyrikan }\end{array}$ & TM & - \\
\hline & & $\begin{array}{l}\text { Fasilitas } \\
\text { Hiburan }\end{array}$ & $\begin{array}{l}\text { Tidak ada fasilitas Hiburan yang mengarah kepada } \\
\text { pornografi dan pornoaksi serta tindakan asusila }\end{array}$ & $\mathrm{M}$ & $\checkmark$ \\
\hline & & & $\begin{array}{l}\text { Apabila menggunakan musik hidup atau musik } \\
\text { rekaman harus tidak bertentangan dengan nilai dan } \\
\text { etika seni dalam Islam }\end{array}$ & $\mathrm{M}$ & $\checkmark$ \\
\hline III & Pengelolaan & $\begin{array}{l}\text { Manajemen } \\
\text { Usaha }\end{array}$ & Memiliki dan menerapkan Sistem Jaminan Halal & M & - \\
\hline & & $\begin{array}{c}\text { Sumber Daya } \\
\text { Manusia }\end{array}$ & $\begin{array}{l}\text { Seluruh karyawan dan karyawati memakai seragam } \\
\text { yang sopan }\end{array}$ & M & $\checkmark$ \\
\hline
\end{tabular}

Sumber: www.parekraf.go.id dan hasil penelitian

Dalam kriteria hilal-1 tersebut, terdapat 27 sub unsur produk yang terdiri dari 14 kriteria mutlak dan 13 kriteria tidak mutlak, 20 sub unsur pelayanan yang terdiri dari 7 kriteria mutlak dan 13 kriteria tidak mutlak, dan 2 sub unsur pengelolaan yang terdiri dari dua kriteria mutlak.

Aplikasi kriteria hotel syariah hilal-1 di hotel Sofyan Inn Specia dapat dijelaskan sebagai berikut:

1. Aspek Produk
Hotel Sofyan Inn Specia telah memenuhi 15 kriteria sub unsur terdiri dari delapan kriteria mutlak dan tujuh kriteria tidak mutlak. Kriteria sub unsur yang belum terpenuhi ada 12 sub unsur yang terdiri dari 6 kriteria mutlak yaitu dari produk toilet umum, kamar tidur tamu, kamar mandi tamu, dan dapur serta 6 kriteria tidak mutlak yaitu dari produk ruang ibadah, ruang karyawan, kolam renang dan spa.

2. Aspek Pelayanan 
Dalam aspek pelayanan, terdapat 6 unsur dan 20 sub unsur. Sub unsur yang telah terpenuhi dalam aspek pelayanan ini adalah 6 sub unsur terdiri dari tiga kriteria mutlak dan tiga kriteria tidak mutlak. Sub unsur yang belum terpenuhi berjumlah 14 unsur yang terdiri dari 4 kriteria mutlak dan 10 kriteria tidak mutlak.

3. Aspek Pengelolaan

Dalam aspek pengelolaan hotel Sofyan Inn Specia telah memenuhi 1 sub unsur mutlak dalam aspek pengelolaan dan belum memenuhi 1 kriteria mutlak yang lain.

\section{KESIMPULAN}

Hasil yang didapatkan dari penelitian yang dilakukan di hotel Sofyan Inn Specia Bandung, yaitu dapat disimpulkan sebagai berikut:

Penelitian ini menyimpulkan bahwa Peraturan Menteri Pariwisata dan Ekonomi Kreatif no. 2 tahun 2014 pasal 1 ayat 3 yang menyebutkan bahwa "usaha hotel syariah adalah hotel yang penyelenggaraannya harus memenuhi kriteria usaha hotel syariah sebagaimana dimaksud dalam peraturan Menteri ini". Kriteria terdiri dari aspek produk, pelayanan, dan pengelolaan. Setelah dilakukan penelitian pada hotel Sofyan Inn Specia, menunjukkan bahwa hotel Sofyan Inn Specia masih belum memenuhi sebagian kriteria mutlak yang terdapat dalam peraturan menteri tersebut, baik dalam aspek produk, pelayanan, maupun pengelolaan. Sehingga, hotel ini belum dapat disebut sebagai usaha hotel syariah menurut peraturan menteri tersebut, dan belum bisa digolongkan menjadi golongan usaha hotel hilal-1 maupun hilal-2.

DAFTAR PUSTAKA

Agus Sulastio.2006. Manajemen Penyelenggaraan Hotel. Bandung:Alfabeta.
Agusnawas. 2000. Operasional Tata Graha Hotel (Hotel Housekeeping Operational). Jakarta: Pustaka Utama Jakarta.

Danu Prasetya.Kamus Lengkap Bahasa Indonesia Masa Kini. Surabaya: Arloka.

Fahruddin Ali Sabri.2010.Perkembangan Hotel Syariah di Indonesia: Mengonsep Pariwisata Islami, Jurnal KARSA vol. XVIII No. 2 Oktober 2010.

Muhammad Syafii Antonio.2001. Bank Syariah: Dari Teori ke Praktek. Jakarta: Gema Insani Pers.

Suharsimi Arikunto.Prosedur Penelitian Suatu Pendekatan Praktek. Jakarta: Bina Aksara.

Umer Chapra.2000. Islam dan Tantangan Ekonomi. Jakarta: Gema Insani Pers.

Muhammad Sharif Chaudrhy.2011.Sistem Ekonomi Islam: Prinsip Dasar (Fundamental of Islamic Economic System). Jakarta: Prenada Media Group.

Fakultas Syariah dan Hukum.2011.Panduan Usulan Penelitian dan Penulisan Skripsi. Fakultas Syariah dan Hukum: UIN Sunan Gunung Djati Bandung.

Lukman Hakim.2002.Prinsip-prinsip Ekonomi Islam. Jakarta: Erlangga.

Mustafa Edwin Nasution.2007.Pengenalan Ekslusif Ekonomi Islam. Cetakan Kedua. Jakarta: Prenada Media Group.

Trisno Tarmoezi dan Heldin Manurung.2007. Hotel Front Office:Profesional Hotel Front Liner. Jakarta:Visipro.

Veitzhal Rivai.2012.Islamic Transaction Law in Business. Jakarta: PT. bumi Aksara.

Wisnu HS Al Bataafi.2006. Housekeeping, Departement Floor and Public Area. Alfabeta:Bandung.

Siti Rohmah.2014.Skripsi, Penerapan Nilai-Nilai Etika Bisnis Islam di Hotel Madani Yogyakarta, UIN Suna Kalijaga Yogyakarta 